\title{
OCCURRENCE OF Blastocystis spp. IN UBERABA, MINAS GERAIS, BRAZIL
}

\author{
Marlene CABRINE-SANTOS(1), Eduardo do Nascimento CINTRA(1), Rafaela Andrade do CARMO(1), Gabriel Antônio Nogueira NASCENTES(2), \\ André Luiz PEDROSA(3), Dalmo CORREIA(4) \& Márcia Benedita de OLIVEIRA-SILVA(3)
}

\begin{abstract}
SUMMARY
Intestinal parasites are a problem for public health all over the world. The infection with Blastocystis, a protozoan of controversial pathogenicity, is one of the most common among them all. In this study, the occurrence of intestinal parasites, with emphasis on Blastocystis, in patients at the Universidade Federal do Triângulo Mineiro was investigated in Uberaba (MG) through microscopy of direct smears and fecal concentrates using Ritchie's method. Feces of 1,323 patients were examined from April 2011 to May 2012. In $28.7 \%$ of them at least one intestinal parasite was identified, and the most frequent organisms were Blastocystis spp. (17.8\%) and Giardia intestinalis (7.4\%). The occurrence of parasitism was higher in children aged $6-10$ years old, and the infection with Blastocystis spp. was higher above the age of six $(p<0.001)$. The exclusive presence of $G$. intestinalis and of Blastocystis spp. was observed in $5.4 \%$ and $12.2 \%$ of the patients, respectively. Regarding patients with diarrheic feces, $8 \%$ revealed unique parasitism of Blastocystis spp. Other intestinal parasites observed in children were Ascaris lumbricoides (0.3\%) and Entamoeba histolytical dispar/moshkovskii (1.4\%). The Ritchie's method was more sensitive (92.8\%) when compared to direct microscopy (89.8\%), with high agreement between them $(97.7 \%$, kappa $=0.92)$. In conclusion, the occurrence of Blastocystis spp. in Uberaba is high and the presence of diarrheic feces with exclusive presence of the parasite of Blastocystis spp. was observed.
\end{abstract}

KEYWORDS: Blastocystis spp.; Intestinal parasites; Stools; Uberaba (MG).

\section{INTRODUCTION}

Intestinal infections by protozoa are frequent all over the world, being most prominent in developing countries, since the majority of the infections are generally acquired by the ingestion of foods or water contaminated by human and/or animal feces, generally caused by the lack of basic sanitation and conditions of hygiene ${ }^{4,6,12}$. In this context the infection with Blastocystis spp., an anaerobic intestinal protozoan is one of the most prevalent ${ }^{6,9,12}$, occurring in approximately $1.5 \%$ to $10 \%$ of the population in developed countries and $30 \%$ to $60 \%$ in developing countries $^{19}$. However, these data are underestimated, since laboratory technicians are generally not sufficiently trained to detect it or simply do not report their findings. Moreover, routine techniques for stool analysis such as the water spontaneous sedimentation (HOFFMANPONS-JANER $)^{8}$ which leads to the breakage of the vacuolar stage of the parasite, is one of the mostly detected stages in the stool examination, leading to the false negative results ${ }^{14}$.

Although the infection with Blastocystis spp. is one of the most prevalent amongst the intestinal parasites, its impact on public health is not known, since its pathogenicity has been noted as controversial by several authors $6,9,10,21$. However, in spite of the controversial issue that Blastocystis pathogenesis represents, there are no explanations for patients who present symptoms like diarrhea, fever, vomit, abdominal pain, and nauseas in the absence of any other parasite but Blastocystis ${ }^{6,9,10}$. In addition to this, studies have shown that stress conditions can lead to increased susceptibility and pathogenicity of Blastocystis, it is also an opportunistic parasite in immunocompromised patients ${ }^{5,16}$. There is a huge lack of information regarding the pathogenesis, the diagnosis and the epidemiology of this protozoan ${ }^{20}$. In this study, it is shown that the occurrence of Blastocystis in Uberaba is high, followed by the infection of Giardia intestinalis, and that direct methods, especially Ritchie's, are suitable for the diagnosis of the parasite. Moreover, the presence of diarrheal stools with unique parasitism by Blastocystis spp. was observed.

\section{MATERIAL AND METHODS}

The present paper is a cross-sectional study with a non-probability sample of patients who were treated at the Universidade Federal do Triângulo Mineiro Hospital, between April 2011 and May 2012. All patients referred to carry out a stool test suffered from acute or chronic diarrhea or complaints of constant abdominal pain and/or weakness was included. Age, presence of underlying diseases, HIV/AIDS or gastrointestinal symptoms were not considered as exclusion criteria. The specimens were examined by the microscopy direct of smears and fecal concentrates by Ritchie' method ${ }^{18}$. Briefly, the examination by direct

(1) Instituto de Ciências da Saúde, Universidade Federal do Triângulo Mineiro, Uberaba/MG, Brazil.

(2) Disciplina de Microbiologia e Imunologia, Instituto Federal de Educação, Ciência e Tecnologia do Triângulo Mineiro (IFTM), Uberaba/MG, Brazil.

(3) Instituto de Ciências Biológicas e Naturais, Universidade Federal do Triângulo Mineiro, Uberaba/MG, Brazil.

(4) Disciplina de Doenças Infecciosas e Parasitárias, Universidade Federal do Triângulo Mineiro, R. Frei Paulino 30, Abadia, Uberaba, Minas Gerais, Brazil.

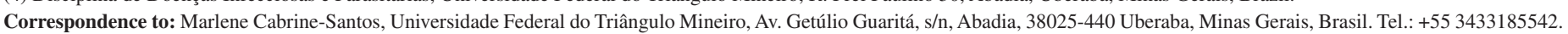

Fax: +55 3433185462. E-mail: marlenecabrine@yahoo.com.br 
CABRINE-SANTOS, M.; CINTRA, E.N.; CARMO, R.A.; NASCENTES, G.A.N.; PEDROSA, A.L.; CORREIA, D. \& OLIVEIRA-SILVA, M.B. - Occurrence of Blastocystis spp. in Uberaba, Minas Gerais, Brazil. Rev. Inst. Med. Trop. Sao Paulo, 57(3): 211-4, 2015.

microscopy was conducted with an amount of stool placed in a drop of Lugol solution in a slide/coverslip and observed by optical microscopy with a $400 \times$ objective lense. Ritchie's method was performed by keeping the feces in $3.7 \%$ formaldehyde, adding ethyl ether and then centrifuging the mixture at $1,200 \times \mathrm{g} / 5 \mathrm{~min}$. The sediment was observed with the $400 \times$ objective. The statistical software Statistica 10.0 (Statsoft, Tulsa, OK, 2011) was used to perform the statistical analysis.

The association between risk factors and presence of Blastocystis spp. was verified by the chi-squared classic or, whenever necessary by the chi-square test with Yates correction and Fisher's exact test. Moreover, the association force was measured by the calculation of the Odds ratio with confidence intervals of $95 \%$. The agreement between the microscopy direct and the Ritchie's method was evaluated by means of Kappa coefficient. Results which demonstrate a level of significance lower than $0.05(p<0.05)$ were considered significant. This study was approved by the ethics committee in research at the UFTM under number 1804.

\section{RESULTS}

Stool specimens from 1,323 patients were examined, with $44.1 \%$ male and $55.9 \%$ female. From the analyzed samples, $28.7 \%$ presented an intestinal pathogenic parasite or not, being Blastocystis spp. (17.8\%) and G. intestinalis (7.4\%) the most observed (Table 1). The known pathogenic parasites analysis showed a positivity of $10.4 \%$ (138/1323), with the highest occurrence detected by $G$. intestinalis. The presence of non-pathogenic parasites occurred in $7.3 \%$ of the samples (Table 1).

Table 1

Occurrence of intestinal parasites in stool samples of patients from the Clinical Hospital at the Universidade Federal do Triângulo Mineiro, Uberaba, MG

\begin{tabular}{lcc}
\hline Positivity of the diagnostic tests & $\mathrm{n}$ & $\%$ \\
\hline Intestinal parasites & 379 & 28.65 \\
Blastocystis sp. & 235 & 17.76 \\
Giardia intestinalis & 98 & 7.41 \\
Entamoeba coli & 59 & 4.46 \\
Endolimax nana & 36 & 2.72 \\
Entamoeba histolytica/dispar/moshkovskii & 26 & 1.97 \\
Taenia sp. & 6 & 0.45 \\
Ascaris lumbricoides & 2 & 0.15 \\
Isospora belli & 1 & 0.08 \\
Strongyloides stercoralis & 2 & 0.15 \\
Chilomastix mesnili & 1 & 0.08 \\
Hookworms & 1 & 0.08 \\
Enterobius vermicularis & 1 & 0.08 \\
Hymenolepis nana & 1 & 0.08 \\
Exclusive presence of Blastocystis & 161 & 12.17 \\
Exclusive presence of Giardia & 71 & 5.37 \\
\hline
\end{tabular}

From the evaluated samples, $33.47 \%$ (442) were from children aged $0-5$ years and $11.04 \%$ (146) were from children aged between 6-10 years
(Table 2), and in $27.8 \%$ and $44.1 \%$ of them, respectively, the presence of parasitism by at least one organism was observed, whether pathogenic or not. G. intestinalis infection occurred in $86.7 \%$ of cases $(85 / 98)$ in patients aged between 0-10 years (Table 2). Ascaris lumbricoides (3, $0.3 \%$ ) and Entamoeba histolytica/dispar/moshkovskii (13, 0.7\%) were also observed in children.

\section{Table 2}

Parasitism by Giardia intestinalis and Blastocystis spp. according to the age group of patients treated at the Clinical Hospital, Universidade Federal do Triângulo Mineiro, Uberaba (MG)

\begin{tabular}{lccc}
\hline Age (years) & No. of patients & $\begin{array}{c}\text { Giardia intes- } \\
\text { tinalis } \\
(\mathrm{n} / \%)\end{array}$ & $\begin{array}{c}\text { Blastocystis } \\
\text { spp. } \\
(\mathrm{n} / \%)\end{array}$ \\
\hline $0-5$ & 442 & $70(15.8)$ & $51(1.5)$ \\
$6-10$ & 146 & $15(10.2)$ & $44(30.1)$ \\
$11-20$ & 103 & $6(5.8)$ & $25(24.1)$ \\
$21-50$ & 407 & $5(1.2)$ & $70(17.2)$ \\
$>50$ & 225 & $2(0.8)$ & $45(20.0)$ \\
\hline Total & 1,323 & 98 & 235 \\
\hline
\end{tabular}

Overall, parasitism was higher in male patients $(32.6 \%)$ than in females $(25.5 \%)(95 \% \mathrm{CI}=1.1$ to $1.79, p<0.005)$ and higher in the range age of $6-10$ years $(95 \% \mathrm{IC}=1.48-3.60 ; p<0.001)$. Interestingly, parasitism of Blastocystis spp. was significantly higher in patients presenting over six years of age $(p<0.001$, Table 2$)$. The analysis of parasitism by $G$. intestinalis or Blastocystis spp. by age in relation to gender showed no significant difference.

The unique presence of Blastocystis in feces occurred in 161/1,323 samples $(12.1 \%)$. The analysis of the consistency of feces at the moment of the examination showed that, among the solid samples, softened and liquid, $12.0 \%$ (107/892), 15.8\% (34/215) and 8.0\% (6/75), respectively, were positive exclusively for Blastocystis spp., showing no statistical difference $(p=0.152)$. The information of the consistency of 14 stool samples with exclusively positivites for Blastocystis sp was not taken.

The analysis by Ritchie's method was more sensitive for the diagnosis of Blastocystis (92.8\%) than that by direct microscopy (89.8\%), with a ratio of $97.7 \%$ agreement $($ Kappa $=0.92)$.

\section{DISCUSSION AND CONCLUSIONS}

In this study the occurrence of intestinal infections by protozoa and/ or helminths in Uberaba (MG) was of $28.7 \%$. However, only $10.4 \%$ of the stool samples presented some pathogenic parasite, in which $7.4 \%$ corresponded to the infection by Giardia that occurred mainly in children between 0-10 years of age. These data are in accordance with other studies carried out in several regions of Brazil ${ }^{11,14,17}$. Regarding age and gender, the presence of intestinal parasites was higher in male children aged between the ages of six and 10 years. In relation to parasitism by Blastocystis (17.8\%) it was higher in patients over six years of age and had no direct relation to gender. $G$. intestinalis infection presented no correlation with gender either. Regarding age, the data agrees with other 


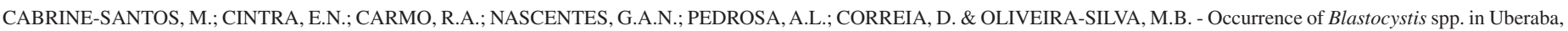
Minas Gerais, Brazil. Rev. Inst. Med. Trop. Sao Paulo, 57(3): 211-4, 2015

studies $^{19}$ and differs from some authors which showed that Blastocystis infection was higher in children than in adults ${ }^{9,14,15}$. In relation to gender, there is no agreement which indicates that gender shows the highest occurrence of Blastocystis spp. ${ }^{14,19}$.

The occurrence of Blastocystis spp. infection was higher when compared with all other parasites, an observation that corroborates other studies ${ }^{4,6,9,12,16}$. The exclusive occurrence of Blastocystis in $8 \%$ of diarrheal stools suggests that it may have a pathogenic character, as some authors agree ${ }^{19,21}$. Some authors observed the presence of Blastocystis in stool samples from HIV-infected, homosexuals, travelers, day care children, animal handlers, and mentally handicapped individuals ${ }^{2,16}$. Besides, in immunocompromised patients, the parasite must be considered pathogenic and patients should be treated accordingly for Blastocystis if no other pathogens are detected ${ }^{2,16}$. According to them, the pathogenicity of Blastocystis is possibly associated with low host immunity, modified intestinal microbiota, and concomitant presence of irritable bowel syndrome and the virulence of the parasite strain. According to CHANDRAMATHI et al. (2014), pathogenicity may also be host stress dependent, which would lead to a suppression of both immune responses and to the oxidant-antioxidant regulatory system. However, more studies are needed to exclude other possible causes of diarrhea, such as rotavirus infection or metabolic disorders.

In the literature, several authors suggest that the search of this protozoan via the direct method ${ }^{6,9,12}$, trichrome staining and cultivation $^{1,10,21}$, states that the concentration methods should not be employed for observation of $B$. hominis as they destroy cell morphology. In this study, both methods, direct and Ritchie's showed higher sensitivity to $89.8 \%$, with a high agreement percentage $(97.7 \%$, kappa $=0.92)$, being appropriate to the diagnosis of Blastocystis. Although the culture is efficient, its cost is higher than the direct method, which has good sensitivity for detecting Blastocystis, since the vacuolar shapes of this parasite are usually released in large amounts in feces. In the authors' experience and unlike that of other authors ${ }^{1}$, staining of fecal smears for direct identification of Blastocystis from feces is not easy to analyze, as the microscopist needs experience to obtain a good result. Thus, the Ritchie's method is a good concentration method, as it is fast and effective, as demonstrated by other authors ${ }^{14}$. The HPJ method is also effective if used to dilute $3.7 \%$ of formaldehyde stools, since the water breaks the vacuolar, granular and amoeboid shapes of the parasite.

Infection with non-pathogenic parasites (Endolimax nana, Entamoeba coli, Chilomastix mesnilli) occurred in $7.3 \%$ of the samples (Table 1). Human infection by non-pathogenic protozoa has been reported by several authors in Brazil ${ }^{7,13,14,22}$ and it highlights the need of their own reports in laboratory reports, therefore it should be considered as an indicator of fecal contamination of food and water consumed by the population.

In conclusion, the occurrence of Blastocystis spp. in Uberaba (MG) was high, this scenario indicates the importance of investigating the main route of parasite transmission and their association with the clinical symptoms manifestation. Furthermore, this study showed that the direct and Ritchie's method were effective for the diagnosis of Blastocystis spp. and that there is a need for the description of commensal protozoa in laboratory reports and for the training of laboratory technicians to improve in order to detect it.

\section{RESUMO}

\section{Ocorrência de Blastocystis spp. em Uberaba, Minas Gerais, Brasil}

Parasitos intestinais são um problema de saúde pública no mundo e a infecção por Blastocystis, protozoário de patogenicidade controversa, é uma das mais frequentes. Nesse estudo foi investigada a ocorrência de parasitos intestinais em pacientes atendidos na Universidade Federal do Triângulo Mineiro, em Uberaba (MG), com ênfase em Blastocystis, pelos métodos parasitológicos direto e de Ritchie. Foram examinadas fezes de 1.323 pacientes de abril/2011 a maio/2012. Em 28,7\% deles foi identificado um parasito intestinal, sendo Blastocystis spp. (17,8\%) e Giardia intestinalis $(7,4 \%)$ os mais frequentes. A ocorrência de parasitismo foi maior em crianças de 6-10 anos e a infecção por Blastocystis spp. foi maior acima de seis anos $(p<0,001)$. Presença exclusiva de $G$. intestinalis e de Blastocystis spp. foi observada em 5,4\% e $12,2 \%$ dos pacientes, respectivamente, sendo que dos pacientes com fezes diarreicas, $8 \%$ apresentavam parasitismo exclusivo por Blastocystis spp. Outros parasitos intestinais observados em crianças foram Ascaris lumbricoides $(0,3 \%)$ e Entamoeba histolytica/dispar/moshkovskii $(1,4 \%)$. O método de Ritchie foi mais sensível $(92,8 \%)$ que o direto $(89,8 \%)$, com alta concordância entre eles $(97,7 \%$, kappa $=0,92)$. Em conclusão, a ocorrência de Blastocystis spp. em Uberaba é elevada e foi observada a presença de fezes diarreicas com parasitismo exclusivo por Blastocystis spp.

\section{ACKNOWLEDGMENTS}

The authors would like to thank Oberdan Ricardo Ribeiro, the laboratory technician at Hospital de Clínicas at UFTM for his assistance in the collection and processing of samples.

Financial support: FAPEMIG- Fundação de Amparo à Pesquisa do Estado de Minas Gerais (APQ04094-10).

\section{AUTHOR'S CONTRIBUTIONS}

MCS and ALP were responsible for the experimental design of the study; ENC and RAC were responsible for the execution techniques and parasitological examination of stools along with MCS and MBOs. GANN was responsible for the statistical analysis and DC for the attending and for the referral of the patients. All authors reviewed and contributed to the writing of this manuscript. MCS is responsible for the manuscript.

\section{CONFLICT OF INTERESTS}

No conflict of interests was declared.

\section{REFERENCES}

1. Amato Neto V, Rodríguez Alarcón RS, Gakiya E, Bezerra, RC, Ferreira CS, Braz LM Blastocistose: controvérsias e indefinições. Rev Soc Bras Med Trop. 2003;36:515-7.

2. Basak S, Rajurkar MN, Mallick SK. Detection of Blastocystis hominis: a controversial human pathogen. Parasitol Res. 2014;113:261-5.

3. Boreham PF, Stenzel DJ. The current status of Blastocystis hominis. Parasitol Today $1993 ; 9: 251$ 
4. Borges JD, Alarcón RSR, Amato Neto V, Gakiya E. Parasitoses intestinais de indígenas da comunidade Mapuera (Oriximiná, Estado do Pará, Brasil): elevada prevalência de Blastocystis hominis e encontro de Cryptosporidium sp e Cyclospora cayetanensis. Rev Soc Bras Med Trop. 2009;42:348-50.

5. Chandramathi S, Suresh K, Sivanandam S, Kuppusamy UR. Stress exacerbates infectivity and pathogenicity of Blastocystis hominis: in vitro and in vivo evidences. PLOS One. 2014;9:e94567.

6. Chen TL, Chan CC, Chen HP, Fung CP, Lin CP, Chan WL, et al. Clinical characteristics and endoscopic findings associated with Blastocystis hominis in healthy adults. Am J Trop Med Hyg. 2003;69:213-6.

7. Cimerman S, Cimerman B, Lewi DS. Prevalence of intestinal parasitic infections in patients with acquired immunodeficiency syndrome in Brazil. Int J Infect Dis. 1999;3:203-6.

8. Hoffman WA, Pons JÁ, Janer JL. Sedimentation concentration method in Schistosomiasis mansoni. Puerto Rico J Public Health. 1934;9:283-98.

9. Idris NS, Dwipoerwantoro PG, Kurniawan A, Said M. Intestinal parasitic infection of immunocompromised children with diarrhea: clinical profile and therapeutic response. J Infect Dev Ctries. 2010;4:309-17.

10. Jantermtor S, Pinlaor P, Sawadpanich K, Pinlaor S, Sangka A, Wilailuckana C, et al. Subtype identification of Blastocystis spp isolated from patients in major hospital in northeastern Thailand. Parasitol Res. 2013;112:1781-6.

11. Ludwig KM, Frei F, Álvares Filho F, Ribeiro-Paes JT. Correlação entre condições de saneamento básico e parasitoses intestinais na população de Assis, Estado de São Paulo. Rev Soc Bras Med Trop. 1999;32:547-55.

12. Miné JC, Rosa JA. Frequency of Blastocystis hominis and other intestinal parasites in stool samples examined at the Parasitology Laboratory of School of Pharmaceutical Sciences at the São Paulo State University, Araraquara. Rev Soc Bras Med Trop. 2008:41:565-9.
13. Moura H, Fernandez O, Viola JPB, Silva SP, Passos RH, Lima DB. Enteric parasites and HIV infection: occurrence in AIDS patients in Rio de Janeiro, Brazil. Mem Inst Oswaldo Cruz. 1989;84:527-33.

14. Nascimento SA, Moitinho ML. Blastocystis hominis and other intestinal parasites in a community of Pitanga City, Paraná State, Brazil. Rev Inst Med Trop Sao Paulo. 2005;47:213-7.

15. Noureldin MS, Shaltout AA, El Hamshary EM, Ali ME. Opportunistic intestinal protozoal infections in immunocompromised children. J Egypt Soc Parasitol. 1999;29:951-61.

16. Paboriboune P, Phoumindr N, Borel E, Sourinphoumy K, Phaxayaseng S, Luangkhot E, et al. Intestinal parasitic infections in HIV-infected patients, Lao People's Democratic Republic. PLOS One. 2014;9:e91452.

17. Rezende CH, Costa-Cruz JM, Gennari-Cardoso ML. Enteroparasitoses in food handlers of the public schools in Uberlândia (Minas Gerais), Brazil. Rev Panam Salud Publica. 1997;2:392-7.

18. Ritchie LS, Lin S, Moon AP, Frick LP, Williams JE, Asakura S, et al. The possible effects of $\mathrm{pH}$ and specific gravity on the ether-sedimentation procedure in concentrating eggs and cysts. Am J Trop Med Hyg. 1960;9:444-9.

19. Stenzel DJ, Boreham PF. Blastocystis hominis revisited. Clin Microbiol Rev. 1996;9:56384.

20. Tan KS, Singh M, Yap EH. Recent advances in Blastocystis hominis research: hot spots in terra incognita. Int J Parasitol. 2002;32:789-804.

21. Tan TC, Ong SC, Suresh KG. Genetic variability of Blastocystis sp isolates obtained from cancer and HIV/AIDS patients. Parasitol Res. 2009;105:1283-6.

22. Velásquez V, Caldera R, Wong W, Cermeño G, Fuentes M, Blanco Y, et al. Elevada prevalência de blastocistose em pacientes do Centro de Saúde de Soledad, Estado Anzoategui, Venezuela. Rev Soc Bras Med Trop. 2005;38:356-7.

Received: 15 April 2014

Accepted: 26 August 2014 